\title{
The Full-Length Form of the Drosophila Amyloid Precursor Protein Is Involved in Memory Formation
}

\author{
Isabelle Bourdet, Thomas Preat, and Valérie Goguel \\ Genes and Dynamics of Memory Systems, Brain Plasticity Unit, CNRS, ESPCI-ParisTech, PSL Research University, 75005 Paris, France
}

\begin{abstract}
The APP plays a central role in AD, a pathology that first manifests as a memory decline. Understanding the role of APP in normal cognition is fundamental in understanding the progression of $\mathrm{AD}$, and mammalian studies have pointed to a role of secreted $\mathrm{APP} \alpha$ in memory. In Drosophila, we recently showed that APPL, the fly APP ortholog, is required for associative memory. In the present study, we aimed to characterize which form of APPL is involved in this process. We show that expression of a secreted-APPL form in the mushroom bodies, the center for olfactory memory, is able to rescue the memory deficit caused by APPL partial loss of function. We next assessed the impact on memory of the Drosophila $\alpha$-secretase kuzbanian (KUZ), the enzyme initiating the nonamyloidogenic pathway that produces secreted APPL $\alpha$. Strikingly, KUZ overexpression not only failed to rescue the memory deficit caused by APPL loss of function, it exacerbated this deficit. We further show that in addition to an increase in secreted-APPL forms, KUZ overexpression caused a decrease of membrane-bound full-length species that could explain the memory deficit. Indeed, we observed that transient expression of a constitutive membrane-bound mutant APPL form is sufficient to rescue the memory deficit caused by APPL reduction, revealing for the first time a role of full-length APPL in memory formation. Our data demonstrate that, in addition to secreted APPL, the noncleaved form is involved in memory, raising the possibility that secreted and full-length APPL act together in memory processes.
\end{abstract}

Key words: $\alpha$-secretase; APPL; Drosophila; kuzbanian; mushroom bodies; short-term memory

\section{Introduction}

APP is a major actor of AD (Zheng and Koo, 2011). APP is a transmembrane protein that undergoes two exclusive processing pathways: the nonamyloidogenic pathway initiated by the $\alpha$-secretase produces a secreted APP form $(\operatorname{sAPP} \alpha)$, while the amyloidogenic pathway leads to the production of amyloid- $\beta$ peptides $(\mathrm{A} \beta)$, which can form toxic extracellular deposits in the brain of AD patients (Turner et al., 2003). For years, the amyloid hypothesis has placed $\mathrm{A} \beta$ at the center of the pathology etiology (Hardy and Selkoe, 2002).

To understand mechanisms underlying the pathology, it is fundamental to understand the role of APP in normal cognition, especially as disruption of APP normal function may contribute to AD (Neve et al., 2000). AD's first symptom is a decline of episodic memory (Förstl and Kurz, 1999), and several studies in mice reported that sAPP $\alpha$ enhances memory (Meziane et al., 1998; Ring et al., 2007). The physiological role of APP is particu-

\footnotetext{
Received May 23, 2014; revised Nov. 7, 2014; accepted Nov. 26, 2014.

Author contributions: I.B., T.P., and V.G. designed research; I.B. and V.G. performed research; I.B. and V.G. analyzed data; I.B., T.P., and V.G. wrote the paper.

T.P. was supported by a grant from the French Agence Nationale de la Recherche. I.B. was supported by the Région Ile-de-France. We thank Doris Kretzschmar (Oregon Health and Science University, Portland, OR) and JeanMaurice Dura (Institut de Génétique Humaine, Montpellier, France) for the kind gift of fly lines. We thank Aurélie Lampin-Saint-Amaux for technical help, and all members of our laboratory for fruitful discussions and critical reading of this manuscript.

The authors declare no competing financial interests.

Correspondence should be addressed to either Valérie Goguel or Thomas Preat, Genes and Dynamics of Memory Systems, Brain Plasticity Unit, CNRS, ESPCI-ParisTech, PSL Research University, 10 rue Vauquelin, 75005 Paris, France. E-mail: valerie.goguel@espci.fr or thomas.preat@espci.fr.

DOI:10.1523/JNEUROSCI.2093-14.2015

Copyright $\odot 2015$ the authors $\quad 0270-6474 / 15 / 351043-09 \$ 15.00 / 0$
}

larly difficult to study because of its numerous proteolytic metabolites. Furthermore, functional studies of the APP pathway in rodents are limited because of redundancy due to three APPrelated genes and the lethality of the triple knock-out (Heber et al., 2000; Herms et al., 2004). In contrast, Drosophila melanogaster expresses a single nonessential APP ortholog, APP-Like (APPL). Importantly, APPL undergoes proteolytic pathways similar to that of APP, and the mammalian homologs of all secretases have been characterized in the fly (Poeck et al., 2012). Despite its relative simplicity, the fly brain is able to drive sophisticated behaviors. Particularly relevant for AD studies, Drosophila is extensively used as a model to study memory, and molecular processes at play are conserved from flies to mammals (McGuire et al., 2005). Neuronal structures underlying olfactory memory are well described. The mushroom bodies (MB), prominent bilateral structures of the fly brain comprising 4000 neurons, have been identified as the center of olfactory learning and memory (Heisenberg, 1998). We have recently shown that APPL is required for memory in the adult MB (Goguel et al., 2011), supporting the hypothesis that APP loss of function might contribute to the appearance of memory deficits in $\mathrm{AD}$.

In the present study, we aimed to characterize which APPL forms are involved in memory. We analyzed short-term memory (STM) after overexpression in the adult MB of either a constitutively secreted APPL form (APPL ${ }^{\text {s; }}$ Torroja et al., 1996) or kuzbanian (KUZ), the Drosophila homolog of the mammalian $\alpha$-secretase ADAM10 (Rooke et al., 1996; Carmine-Simmen et al., 2009). While APPL $^{s}$ overexpression was fully able to rescue the STM deficit caused by an APPL partial loss of function, KUZ overexpression strikingly turned out to exacerbate this deficit. 
We show that in this context, KUZ overexpression generated a decrease of membrane-bound full-length APPL, and further demonstrate that expression of a membrane-bound mutant form of APPL (Torroja et al., 1996) was sufficient to rescue the STM deficit caused by Appl inhibition. Our data point to a requirement for memory processes of both secreted and nonproteolyzed forms of APPL.

\section{Materials and Methods}

Drosophila stocks. All fly strains were outcrossed to a Canton Special genetic background. The UAS-kuzbanian ( $k u z$ ) line was kindly provided by D. Kretzschmar (Carmine-Simmen et al., 2009). The Appl $l^{d} ; M B S w$ line was constructed using $A p p l^{d}$-null mutant flies (Luo et al., 1992) and the Gal4-inducible MB247-Switch driver (Mao et al., 2004). The deficient $A p p l^{d} w^{*}$ line used for rescue experiments was a gift from J. M. Dura (Soldano et al., 2013). The UAS-APPL, UAS-APPL $L^{s}$, and UAS-APPL $L^{s d}$ lines were described previously (Torroja et al., 1996, 1999). The specific Appl-RNAi used in this study is the transformant \#108312 from the Vienna Drosophila RNAi Center. For behavioral experiments, flies were raised on standard medium at $18^{\circ} \mathrm{C}$ with $60 \%$ humidity under a $12 \mathrm{~h}$ light/dark cycle. As the Appl gene is located on the X chromosome, only females were analyzed in experiments that involved $A p p l^{d}$ genotypes. To induce transgene expression, the GeneSwitch system was used as described previously (Mao et al., 2004). A stock solution of RU486 (SPIBio; $10 \mathrm{~mm}$ in $80 \%$ ethanol) was mixed into molten food at $65^{\circ} \mathrm{C}$ to a final concentration of $200 \mu \mathrm{M}$.

Behavior experiments. Flies were trained with classical olfactoryaversive conditioning protocols as described previously (Pascual and Préat, 2001). One to 2-d-old flies were kept on RU486-containing medium (RU) for $48 \mathrm{~h}$ before conditioning, and until testing when performed $24 \mathrm{~h}$ later. Training and testing were performed at $25^{\circ} \mathrm{C}$ with $80 \%$ humidity. Conditioning was performed on samples of $30-40$ flies with 3-octanol ( $>95 \%$ purity; Fluka 74878 , Sigma-Aldrich) and 4-methylcyclohexanol (99\% purity; Fluka 66360, Sigma-Aldrich) at 0.360 and $0.325 \mathrm{~mm}$, respectively. Odors were diluted in paraffin oil (VWR International, Sigma-Aldrich). Memory tests were performed with a T-maze apparatus (Tully and Quinn, 1985). Flies could choose for 1 min between two arms, each delivering a distinct odor. An index was calculated as the difference between the numbers of flies in each arm divided by the sum of flies in both arms. A performance index was then reported from the average of two reciprocal experiments with either octanol or methylcyclohexanol as conditioned stimulus. For odoravoidance tests after electric shock exposure, and response to electric shock, flies were treated as described previously (Pascual and Préat, 2001).

Quantitative PCR. Flies were raised at $25^{\circ} \mathrm{C}$ before total RNA extraction from 50 female heads with the RNeasy Plant Mini Kit (Qiagen). Samples were submitted to DNase I treatment (BioLabs), and further reverse transcribed with oligo(dT)20 primers using the SuperScript III First-Strand kit (Life Technologies) according to the manufacturer's instructions. To specifically amplify the $A p p l^{s} \mathrm{cDNA}$, we used a primer (5'-CGCAGCGAGAAGCTCGATTA-3') that hybridizes at the site of the stop codon, which was introduced in the Appl sequence to generate the $A P P L^{s}$ construct (Torroja et al., 1996). We compared the level of the target cDNA to that of the $\alpha$-Tub84B (CG1913) cDNA, which was used as a reference. Amplification was performed using a LightCycler 480 (Roche) in conjunction with the SYBR Green I Master (Roche). For each experiment, reactions were performed in triplicate for two dilutions of each cDNA. Each datum represents two to four independent experiments. Specificity and size of amplification products were assessed by melting curve analyses and agarose gel electrophoresis, respectively. Expression relative to the reference is expressed as a ratio $\left(2^{-\Delta C p}\right.$, where $\mathrm{Cp}$ is the crossing point).

Protein analyses. Proteins were extracted from 140 female fly heads after $48 \mathrm{~h}$ of RU induction at $18^{\circ} \mathrm{C}$. Protein extracts were fractioned in RIPA buffer containing protease and phosphatase inhibitors (Roche) using sequential centrifugation as described previously (Lallemand et al., 2003). Samples were separated using SDS-PAGE gels containing a gradi- ent of 3-8\% acrylamide (Life Technologies) and transferred to nitrocellulose membrane (GE Healthcare). Membranes were cut into two parts and the higher one was probed with anti-APPL that binds to the APPL ectodomain (Ab952M; Torroja et al., 1996) at a dilution of 1:10,000. The lower part of the membrane was probed with either anti- $\gamma$-Tub (QG-17; Sigma-Aldrich, dilution $1: 20,000)$ to analyze membrane fractions or anti- $\alpha$-Tub (T6199; Sigma-Aldrich, 1:40,000 dilution) to analyze soluble fractions. Western blots were routinely developed using the ECL system (Life Technologies). Protein levels were quantified using ImageQuant TL software (GE Healthcare). Following normalization to loading controls, the levels of each APPL-reactive band were expressed as relative to the total amount of APPL detected in heterozygous Appl $/+; M B S w /+$ flies from the same Western blot experiment. Three independent protein extractions were quantified 10 (membrane fractions) and 11 (soluble fractions) times on four independent Western blots.

Statistical analyses. Memory scores are displayed as mean \pm SEM. To compare performance indexes from more than two groups, statistical analyses were performed through a one-way ANOVA, followed by Newman-Keuls pairwise comparisons. Overall ANOVA $p$ value is given in the legends along with the value of the corresponding Fisher distribution $F_{(x, y)}$, where $x$ is the number of degrees of freedom for groups and $y$ the total number of degrees of freedom for the distribution. Asterisks on the figure represent the least significant of the pairwise post hoc comparisons between the genotype of interest and its controls, following the usual nomenclature. To compare memory scores of two groups, Student's $t$ tests were used with $p<0.05$ as a significance threshold. mRNA quantification measurements were analyzed from $2^{-\Delta \mathrm{CP}}$ ratios in the same way.

\section{Results}

Several reports have shown that APP is involved in memory in mammals. In Drosophila, we recently showed that APPL expression is required in the $\mathrm{MB}$ of young adults for long-term memory (LTM) formation (Goguel et al., 2011). Because there are numerous APPL metabolites, we aimed to identify which APPL species are involved in memory processes. To this end, we addressed whether the expression of distinct mutant forms of APPL could rescue the memory deficit observed in flies containing a reduced level of APPL protein.

To analyze memory, we used a classical conditioning of an odor-avoidance response. In this paradigm, groups of flies are successively exposed to two distinct odors, only one of which is associated with electric pulses. Learning and STM are assessed immediately and $2 \mathrm{~h}$, respectively, after one training cycle. Unlike STM, LTM is a consolidated memory whose formation relies on de novo protein synthesis (Tully et al., 1994), and it is assessed $24 \mathrm{~h}$ after five-spaced training sessions.

In our previous work (Goguel et al., 2011), we knocked down APPL expression in adult MB by RNAi using the conditional MB247-Switch driver (MBSw; Mao et al., 2004) and UAS-RNAi transgenes. The MBSw driver encodes a Gal4-Switch fusion protein that becomes active when flies are fed with the RU ligand (Roman et al., 2001). However, this knockdown strategy could not be used in the present study, as an Appl RNAi would target both endogenous Appl RNA and that resulting from the construct used to conduct rescue experiments. To circumvent this issue, we took advantage of $A p p l^{d}$-null mutant flies (Luo et al., 1992), and generated $A p p l^{d}$ flies carrying the MBSw driver $\left(A p p l^{d}\right.$; $M B S w)$. As previously described (Luo et al., 1992), homozygous $A p p l^{d} ; M B S w$ flies exhibited an impairment in electric shock avoidance (Fig. $1 A$ ), as well as an apparent defect in learning that might result from the impairment in shock reactivity (Fig. $1 B$ ). These data are consistent with the fact that Appl deletion leads to subtle abnormal morphology of the MB lobes (Li et al., 2004), and a more recent study showing the role of APPL in brain wiring during development (Soldano et al., 2013). Interestingly, Sol- 

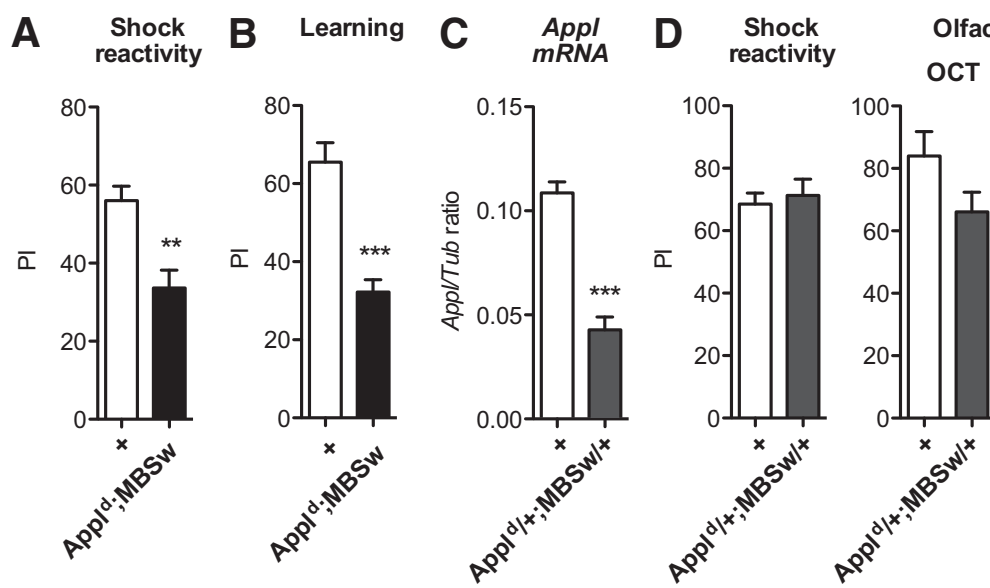

Olfactory acuity

$\mathrm{MCH}$

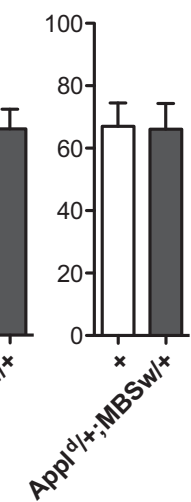

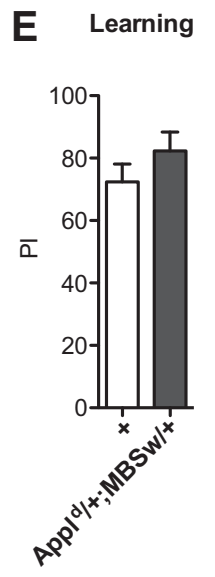

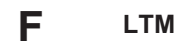

G

H

STM

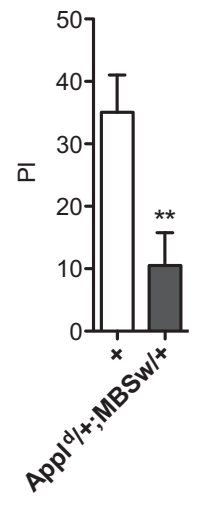

the fact that unlike $A p p l^{d}$-null mutant, flies expressing $40 \%$ of the wild-type level of Appl mRNA possess brain structures involved in olfactory learning and memory that are not affected.

To better characterize the memory deficit of $A p p l^{d} /+; M B S w /+$ heterozygous flies, we analyzed their LTM performances. Consistent with the results previously observed with flies expressing specific $A p p l$ RNAi in adult MB (Goguel et al., 2011), $A p p l^{d} /+; M B S w /+$ heterozygous flies exhibited an LTM impairment (Fig. $1 F$ ). In addition, $A p p l^{d} /+; M B S w /+$ heterozygous flies exhibited a slight but significant STM defect compared with wild-type (Fig. 1G), whereas we previously observed that STM was not affected in Appl RNAi-G3- and Appl RNAi-42673expressing flies (Goguel et al., 2011). In our previous study, APPL protein level was decreased by $39 \%$ in the MB as estimated by immunohistochemistry experiments (Goguel et al., 2011), whereas in the present work, Appl mRNA reduction in the fly head estimated by qPCR was $60 \%$, suggesting that APPL protein level in the $\mathrm{MB}$ is lower in $A p p l^{d} /+; M B S w /+$ heterozygous flies than that previously achieved by RNAi induction. Thus, we hypothesized that the more APPL expression is reduced, the stronger the memory phenotypes observed. Indeed LTM is dependent on more advanced mechanisms than STM and is thus likely more sensitive to disturbance (Dubnau and Tully, 1998). To further address this question, we used a more efficient Appl-RNAi construct (RNAi-108312) to achieve a higher extent of APPL loss of function. Efficiency of Appl RNAi-108312 was assessed by driving its transcription with the pan-neuronal elav-Gal4 driver. qPCR analyses revealed that elav/+;+/RNAi-108312 flies express an Appl/Tub ratio of $0.055 \pm 0.003$ relative to the elav/+ control, whereas previously published results indicated relative ratios of 0.13 for elav/+;42673/+ and 0.25 for elav/+;G3/+ flies (Goguel et al., 2011), showing that the RNAi-108312 construct leads to a higher $A p p l$ knockdown than

dano et al. (2013) showed that $\mathrm{Appl}^{d} /+$ heterozygous flies retaining one copy of the Appl wild-type gene do not undergo any MB developmental alteration. We thus hypothesized that $A p p l^{d} /+$; $M B S w /+$ heterozygous flies might constitute a tool to analyze the role of the APPL pathway in memory. As expected, measurement of Appl expression in $A p p l^{d} /+; M B S w /+$ fly heads by real-time PCR showed a strong reduction in Appl mRNA levels compared with wild-type (Fig. 1C). Interestingly, and in contrast to the $A p p l^{d} ; M B S w$-null mutant, $A p p l^{d} /+; M B S w /+$ heterozygous flies showed wild-type shock reactivity (Fig. $1 D$ ), and also wild-type olfactory acuity (Fig. 1D). Furthermore, $A p p l^{d} /+; M B S w /+$ flies displayed a normal learning (Fig. $1 E$ ). These data are consistent with the RNAi constructs previously used. After $48 \mathrm{~h}$ of RU feeding, MBSw/RNAi-108312 flies exhibited an STM deficit (Fig. $1 H$ ). This deficit was only observed when flies were fed with RU to induce RNAi expression (Fig. $1 H$ ), showing that it is specifically caused by RNAi induction in the adult MB. Therefore, decreasing APPL expression in the MB leads to a slight STM impairment that may not be observed when the reduction of Appl level is less substantial. The memory deficit is thus correlated to the extent of $A p p l$ level decrease in the MB. In conclusion, $A p p l /+; M B S w /+$ heterozygous flies should constitute an effective tool to conduct STM rescue experiments in APPL partial loss of function (LOF). 
A

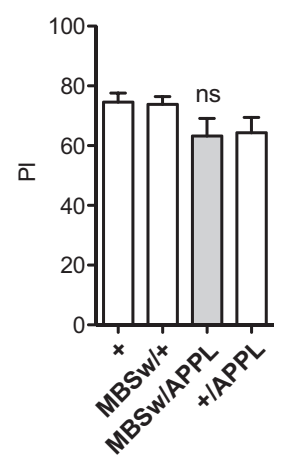

B

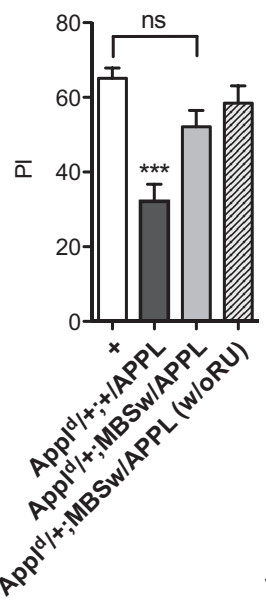

C Appl mRNA

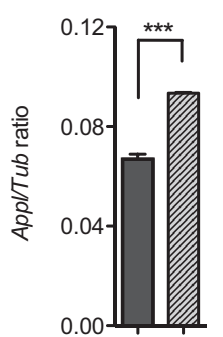

A

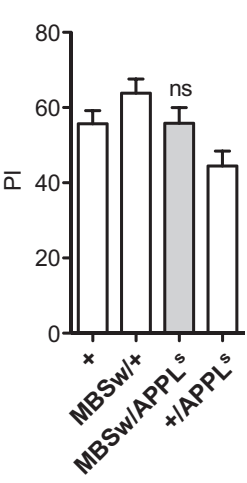

B

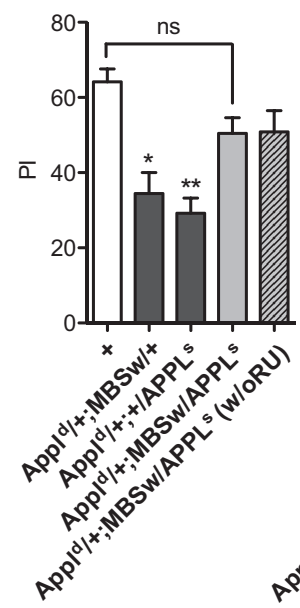

C $\quad A p p I^{s}$ mRNA

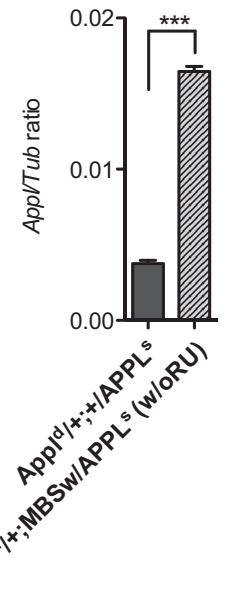

Figure 2. Expression in the MB of wild-type APPL rescues the memory deficit caused by APPL partial LOF. Unless indicated ( $\boldsymbol{B}, \boldsymbol{C}, \mathrm{w} / \mathrm{0} \mathrm{RU})$, flies were fed with RU for $48 \mathrm{~h} . \boldsymbol{A}, \boldsymbol{B}$, Flies were submitted to one-cycle training, and memory was tested $2 \mathrm{~h}$ later. $A, M B S w / A P P L$ flies exhibit STM performances similar to control groups $\left(F_{(3,55)}=2.143, p=0.1060, n \geq 11\right)$. $\boldsymbol{B}$, Rescue experiments. Appl ${ }^{d} /+; M B S W / A P P L$ flies display a score significantly higher than that of $A p p I^{d} /+;+/ A P P L$ flies $\left(F_{(3,84)}=12.88, p=0.0001, n \geq 19 ;\right.$ Newman-Keuls post hoc, ${ }^{* * *} p<0.001$ ), and similar to wild-type $(+)$ control flies (Newman-Keuls post hoc, $p>0.05$ ). $A p p I^{d} /+; M B S W / A P P L$ flies not fed with RU exhibit scores similar to flies of the same genotype fed with RU (Newman-Keuls post hoc, $p>0.05$ ). C, The MBSw driver leads to an increase in App/levels in the absence of RU induction. Total RNA was extracted from Appl $/++; /$ APPL and $A p p I^{d} /+; M B S W / A P P L$ fly heads, respectively, and further reverse transcribed. Resulting CDNA was quantified by qPCR using tubulin (Tub) expression as a reference $\left(t\right.$ test, ${ }^{* * *} p<0.0001$, $n=4)$. Error bars indicate mean \pm SEM. PI, Performance Index.

To validate this tool we first expressed the wild-type APPL form and analyzed its capacity to restore the STM deficit of $\mathrm{Appl}^{d} /+$; $M B S w /+$ heterozygous flies. When APPL overexpression was driven in the MB of wild-type flies $(M B S w / A P P L)$, it did not alter $2 \mathrm{~h}$ memory (Fig. 2A). APPL overexpression in the MB of $A p p l^{d} /+$ heterozygous flies $\left(A p p l^{d} /+; M B S w / A P P L\right)$ led to a memory score similar to wild-type (Fig. $2 B$ ), showing that APPL overexpression in the MB leads to a rescue of the STM deficit caused by the deletion of one of the two copies of the Appl gene. When $A p p l^{d} /+; M B S w / A P P L$ flies were not fed with RU, STM scores were similar to wild-type and to flies of the same genotype fed with RU (Fig. 2B). Thus, we also observe a rescue of the memory deficit in the absence of RU induction. We hypothesized that this phenotype resulted from the expression in the $\mathrm{MB}$ of the $U A S-A P P L$ transgene, as Gal4-Switch may be partially active in the absence of RU feeding. To assess Appl expression in the absence of RU induction, we performed qPCR analyses. We observed that without induction, Appl $/+; M B S w / A P P L$ flies expressed a significant increase in Appl mRNA levels compared with that of $A p p l^{d} /+;+/ A P P L$ flies (Fig. 2C). Considering that RNA was extracted from the whole brain, whereas APPL expression due to the activity of the Gal4-Switch was restricted to the MB, APPL level of expression in the MB should be substantial. The memory impairment of $A p p l^{d} /+$ flies is very likely caused by a functional deficit in the adult, so we conclude that APPL overexpression rescues the memory deficit caused by a partial reduction of endogenous APPL levels.

As the mammalian secreted fragment produced from the $\alpha$-secretase cleavage pathway, $\operatorname{sAPP} \alpha$, is the prime candidate for a role in memory (Meziane et al., 1998; Bour et al., 2004; Ring et al., 2007; Taylor et al., 2008), we next aimed to analyze the secreted-

Figure 3. Expression of secreted APPL rescues the memory deficit caused by APPL partial LOF. Unless indicated $(\boldsymbol{B}, \boldsymbol{C}, \mathrm{w} / 0 \mathrm{RU})$, flies were fed with RU for $48 \mathrm{~h}$. $\boldsymbol{A}, \boldsymbol{B}$, Flies were submitted to one-cycle training and memory was tested $2 \mathrm{~h}$ later. $\boldsymbol{A}, A P P L^{5}$ overexpression in the MB does not impact STM. MBSW/APPL $L^{5}$ flies exhibit STM performances similar to control groups $\left(F_{(3,87)}=\right.$ $4.625, p=0.0048, n \geq 18$; Newman-Keuls post hoc, $p>0.05)$. + $/ A P L^{5}$ flies exhibit an STM score similar to wild-type $(+)$ flies (Newman-Keuls post hoc, $p>0.05$ ). $\boldsymbol{B}$, Rescue experiments. $A p p I^{d} /+; M B S W / A P P L^{s}$ flies display a score significantly higher than that of $A p p I^{d} /+; M B S W /+$ and $A p p I^{d} /+;+/ A P P L^{s}$ flies, respectively $\left(F_{(4,84)}=9.197, p<0.0001\right.$, $n \geq 15$; Newman-Keuls post hoc, $A p p I^{d} /+; M B S W / A P P L^{s}$ vs $A p p I^{d} /+; M B S w /+{ }^{*} p<0.05$, $A p p I^{d} /+; M B S W / A P P L^{s}$ vs Appl $\left.{ }^{d} /+;+/ A P P L^{s * *} p<0.005\right)$, and similar to wild-type $(+)$ control flies (Newman-Keuls post hoc, $p>0.05$ ). Appld $/+; M B S w / A P P L^{s}$ flies not fed with RU exhibit scores similar to flies of the same genotype fed with RU (Newman-Keuls post hoc, $p>0.05) . C, A P P L^{5}$ is expressed in the absence of RU feeding. Total RNA was extracted from $A p p I^{d} /+;+/ A P P L^{s}$ and $A p p I^{d} /+; M B S W / A P P L^{s}$ fly heads and further reverse transcribed. CDNA resulting specifically from the $A P P L^{s}$ construct was quantified by $q P C R$ using tubulin (Tub) expression as a reference ( $t$ test, ${ }^{* *} p<0.001, n=2$ ). Error bars indicate mean \pm SEM. PI, Performance Index.

APPL form. For this purpose, we took advantage of a constitutively secreted-APPL mutant protein. A stop codon introduced in the Appl sequence generates a 788 aa soluble N-terminal fragment of APPL (APPL ${ }^{\text {; }}$; Torroja et al., 1996), which has been put under control of the UAS expression system to allow for controlled expression patterns (UAS-APPL $L^{s}$; Torroja et al., 1999). To assess $\mathrm{APPL}^{\mathrm{s}}$ function in memory, we induced its expression in the MB for $48 \mathrm{~h}$ before conditioning and analyzed memory performances $2 \mathrm{~h}$ after. In flies expressing a wild-type level of endogenous APPL, overexpression of APPL ${ }^{s}$ in the $\mathrm{MB}\left(M B S w / A P P L^{s}\right)$ led to a memory score that was not significantly different from that of control flies (Fig. 3A), showing that expression of a secreted-APPL form in the MB of young adult flies does not increase their STM performances. We next analyzed whether $\mathrm{APPL}^{\mathrm{s}}$ expression in the MB of APPL partial LOF flies could rescue their STM deficit. Heterozygous $A p p l /+; M B S w /+$ and Appl/+;+/APPL flies showed an STM deficit (Fig. 3B), while $\mathrm{APPL}^{\mathrm{s}}$ expression $\left(A p p l^{d} /+; M B S w / A P P L^{s}\right)$ led to the restoration of a wild-type STM score (Fig. $3 B$ ). This result shows that a secreted form of APPL is involved in memory processes. We observed that $A p p l^{d} /+; M B S w / A P P L^{s}$ flies that were not fed with RU also exhibited a wild-type STM score (Fig. $3 B$ ). To assess $A p p l^{s}$ expression in the absence of RU, we performed qPCR analyses. We observed an intrinsic level of $A p p l^{s}$ expression in the absence of Gal4 driver (Fig. 3C, $A p p l^{d} /+;+/ A P P L^{s}$ ). In the presence of the MBSw driver, $A p p l^{d} /+; M B S w / A P P L^{s}$ flies not fed with RU expressed a fivefold increase of $A p p l^{s}$ mRNA compared with the 
control (Fig. 3C). This result indicates that in the absence of RU, the Gal4-Switch protein drives expression of the UAS-APPL transgene. In conclusion, expression of secreted APPL is able to rescue the memory deficit caused by the reduction of endogenous APPL.

To get further insight into secreted-APPL function in memory, we next analyzed the influence on memory of the overexpression of the Drosophila $\alpha$-secretase, KUZ (Rooke et al., 1996), the enzyme that initiates the nonamyloidogenic pathway (Carmine-Simmen et al., 2009). Wild-type KUZexpressing flies $(M B S w / k u z)$ exhibited a memory score that was not significantly different from that of $+/ k u z$ control flies (Fig. $4 A$ ), showing that, similarly to $\mathrm{APPL}^{\mathrm{s}}, \mathrm{KUZ}$ overexpression in the MB of young adult flies has no impact on STM. We next studied whether overexpression of the $\alpha$-secretase could rescue the memory deficit caused by APPL partial LOF. Unexpectedly, KUZexpressing flies $(A p p l /+; M B S w / k u z)$ showed an STM score significantly lower than their genetic controls (Fig. 4B). Thus, not only did KUZ overexpression fail to rescue the memory deficit caused by APPL partial LOF, but even more, it exacerbated this deficit. Appl/+;MBSw/kuz flies exhibited similar scores whether or not they were fed with RU for $48 \mathrm{~h}$ before conditioning (Fig. $4 B)$. Kuz mRNA quantification indicated that KUZ is overexpressed in the absence of RU feeding (data not shown), showing again that the Gal4-Switch driver is partially active under these conditions. Appl/+;MBSw/kuz flies fed with RU and tested immediately after conditioning exhibited wild-type learning (Fig. $4 C)$. Their ability to avoid electric shocks as well as their olfactory acuity to each odor after electric shock exposure were unaffected (Fig. 4D), showing that they perceived the stimuli used for conditioning normally. These data suggest that brain structures required for olfactory memory are not affected in $A p p l /+; M B S w /$ kuz flies.

We next verified the level of $k u z$ overexpression in wild-type and APPL LOF genetic contexts. qPCR analyses revealed that the level of $k u z$ mRNA was similar in MBSw/kuz and $A p p l^{d} /+; M B S w /$ $k u z$ fly heads (Fig. $4 E$ ), indicating that the augmentation of the memory deficit observed in $A p p l^{d} /+; M B S w / k u z$ flies is not due to an increase in KUZ expression level compared with that of $M B S w / k u z$ flies. Altogether, the data show that in an APPL partial LOF background, overexpression of the $\alpha$-secretase, KUZ, is deleterious for memory. This result in apparent contradiction to that observed with $\mathrm{APPL}^{\mathrm{s}}$ overexpression suggests that increasing secreted APPL is not the only consequence of KUZ overexpression.

KUZ has substrates additional to APPL (Pan and Rubin, 1997; Lieber et al., 2002). However, because KUZ overexpression affects STM only when APPL levels are reduced, the results indicate that the memory deficit is caused by an interaction between KUZ and the APPL pathway. To get an insight into this interaction, we first analyzed whether the memory deficit induced by KUZ overexpression in $\mathrm{Appl}^{d} /+; M B S w / k u z$ flies was linked to a modulation of endogenous Appl expression. Appl mRNA level was similar in $A p p l^{d} /+; M B S w /+$ and $A p p l^{d} /+; M B S w / k u z$ flies (Fig. $5 A$ ), showing that the mechanism by which KUZ exacerbates the memory deficit is not through modulation of Appl transcription, but rather through APPL processing. We next analyzed the effect of KUZ overexpression on APPL protein steady-state levels. Western blots were performed after fractionation of fly head lysates. As expected, the data show that APPL-secreted forms revealed in the soluble fraction were enriched upon KUZ overexpression (Fig. $5 B$ ). In addition, we observed that fulllength APPL (fl-APPL) levels present in the membrane fraction were decreased by $30 \%$ in $A p p l^{d} /+; M B S w / k u z$ compared with
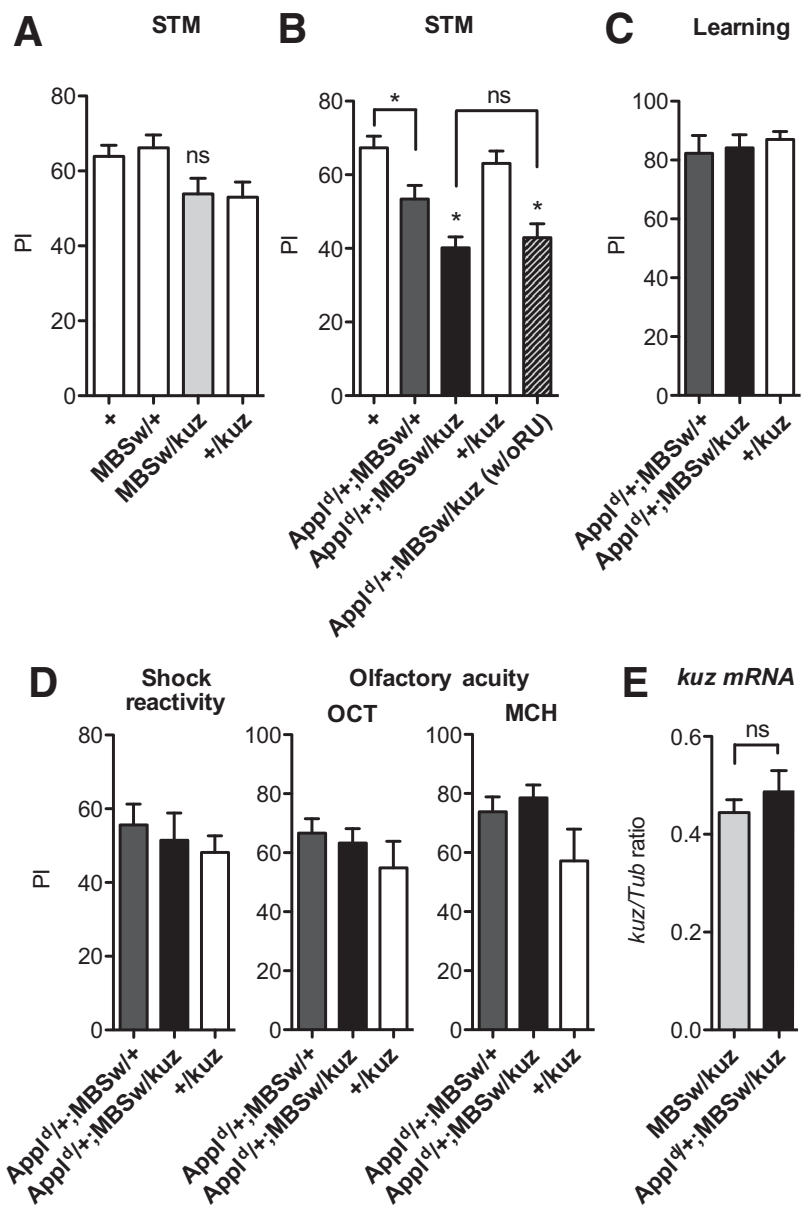

Figure 4. KUZ overexpression exacerbates the memory deficit caused by APPL partial LOF. Unless indicated ( $\boldsymbol{B}, w / 0 \mathrm{RU})$, flies were fed with RU for $48 \mathrm{~h}$ before conditioning or total RNA extraction to induce the expression of the UAS-kuz transgene. $\boldsymbol{A}, \boldsymbol{B}$, Flies were submitted to one-cycle training and tested $2 \mathrm{~h}$ later. $\boldsymbol{A}$, KUZ overexpression in wild-type flies does not impact STM. The score of $M B S W / k u z$ flies is similar to that of the genetic control groups $\left(F_{(3,90)}=3.342\right.$, $p=0.0229, n \geq 21)$. $\boldsymbol{B}, \mathrm{KUZ}$ overexpression in APPL partial LOF flies exacerbates their STM deficit. Heterozygous Appl ${ }^{d} /+; M B S W /+$ flies exhibit an STM score significantly lower than the wild-type $(+)$ control $\left(F_{(4,135)}=11.83, p<0.0001, n \geq 25\right.$; Newman-Keuls post hoc, ${ }^{*} p<$ 0.05). Appl ${ }^{d} /+; M B S w / k u z$ flies perform significantly worse than both genetic controls (Newman-Keuls post hoc, $\left.{ }^{*} p<0.05\right)$. Appl $/+; M B S w / k u z$ flies not fed with RU display scores significantly different from control groups (Newman-Keuls post hoc, ${ }^{*} p<0.05$ ) and similar to $A p p I^{d} /+; M B S w / k u z$ flies fed with RU (Newman-Keuls post hoc, $\left.p>0.05\right)$. C, Learning is not affected. Learning was assessed by testing flies immediately after one-cycle training. Appl ${ }^{d} /+$; MBSw/kuz flies exhibit scores indistinguishable from controls $\left(F_{(2,21)}=0.2516, p=0.7801\right.$, $n \geq 7)$. $\boldsymbol{D}$, Neither shock reactivity $\left(F_{(2,42)}=0.3435, p=0.7113, n \geq 13\right)$ nor olfactory acuity (octanol, $F_{(2,40)}=0.8994, p=0.4153, n \geq 9$; methylcyclohexanol, $F_{(2,42)}=2.694, p=$ $0.0798, n \geq 9)$ is impaired in $A p p l^{d} /+; M B S w / k u z$ flies. $E, q P C R$ analysis of $k u z$ expression. Total RNA was extracted from $M B S w / k u z$ and $A p p I^{d} /+; M B S W / k u z$ fly heads, respectively. Resulting cDNA was quantified using tubulin (Tub) expression as a reference. Results shown are ratios to the reference. kuz mRNA level is similar in MBSw/kuz and $A p p I^{d} /+; M B S w / k u z$ flies ( $t$ test, $p=$ $0.4184, n=3$ ). Error bars indicate mean \pm SEM. PI, Performance Index; OCT, octanol; MCH, methylcyclohexanol.

$A p p l^{d} /+; M B S w /+$ control flies (Fig. $5 C$ ). The results thus show that KUZ overexpression leads to a substantial increase of secreted APPL and a concomitant decrease of membrane-bound fl-APPL forms, suggesting that the deleterious impact on memory of the $\alpha$-secretase overexpression is caused by a decrease of membrane fl-APPL protein.

To get an insight into the influence of fl-APPL on memory, we used the APPL ${ }^{\text {sd }}$ (APPL secretion-defective) mutant form of APPL (Torroja et al., 1996, 1999). APPL ${ }^{\text {sd }}$ carries a short deletion 
encompassing the $\alpha$ - and $\beta$-cleavage sites that thus prevents its proteolytic cleavage. In consequence, $\mathrm{APPL}^{\text {sd }}$ is only expressed as a transmembrane protein. When overexpressed for $48 \mathrm{~h}$ in the MB of wild-type flies $\left(M B S w / A P P L^{s d}\right)$, APPL $^{\text {sd }}$ mutant form did not affect STM (Fig. 6A). We next overexpressed APPL ${ }^{\text {sd }}$ in an APPL partial LOF genetic background. Interestingly, $A p p l^{d} /+; M B S w / A P P L^{s d}$ flies fed with RU showed an STM performance significantly higher than that of $A p p l^{d} /+$; $M B S w /+$ and $A p p l^{d} /+;+/ A P P L^{s d}$ flies, and indistinguishable from wild-type (Fig. 6B). In contrast, in the absence of RU-feeding, $A p p l^{d} /+; M B S w / A P P L^{s d}$ flies exhibited scores that were indistinguishable from that of $A p p l^{d} /+; M B S w /+$ and $A p p l^{d} /+;+/ A P P L^{s d}$ flies, and significantly lower than that of wild-type flies (Fig. $6 B)$. The data show that the induction of $\mathrm{APPL}^{\text {sd }}$ transient expression in the adult $\mathrm{MB}$ rescues the STM defect caused by Appl reduction. This result also demonstrates that the STM deficit observed in $A p p l^{d} /+; M B S w /+$ flies (Fig. $1 G$ ) is indeed the result of a functional deficit in the adult. In conclusion, APPL ${ }^{\text {sd }}$ is able to fully rescue the memory deficit caused by APPL partial LOF, consistent with the fact that KUZ overexpression leads to decreased fl-membrane-bound APPL, and is associated with an exacerbation of memory deficits.

We next aimed to analyze whether the distinct APPL forms used in this study could rescue the LTM deficit caused by the reduction of endogenous APPL levels. As expected, we observed that overexpression of the wild-type APPL form could totally rescue the LTM impairment caused by APPL partial LOF (Fig. $7 A$ ). In contrast, neither $\mathrm{APPL}^{\mathrm{s}}$ nor APPL ${ }^{\text {sd }}$ expression could rescue the LTM deficit (Fig. $7 B, C)$. These data thus indicate that overexpression of either secreted APPL or flmembrane-bound APPL alone is unable to restore wild-type LTM. Although it is difficult to conclude from these negative results, it is possible that both SAPPL and fl-APPL are required for LTM formation, but that either their ratio or their respective abundance is not able to sustain LTM.

\section{Discussion}

The majority of studies into APP biology have focused on pathogenic mechanisms. However, it remains crucial to understand the normal physiological function of APP, especially as it is possible that APP loss of function elicits early cognitive impairment in AD patients. Here, we show that overexpression of secreted APPL rescues the short-term memory deficit caused by a reduction of APPL level. In sharp contrast, overexpression of the $\alpha$-secretase, KUZ, which produces sAPPL, exacerbates the memory impairment, a phenotype that is likely due to a deficit in full-length APPL protein level. Supporting this hypothesis, we further dem-
B Soluble fraction

Soluble APPL
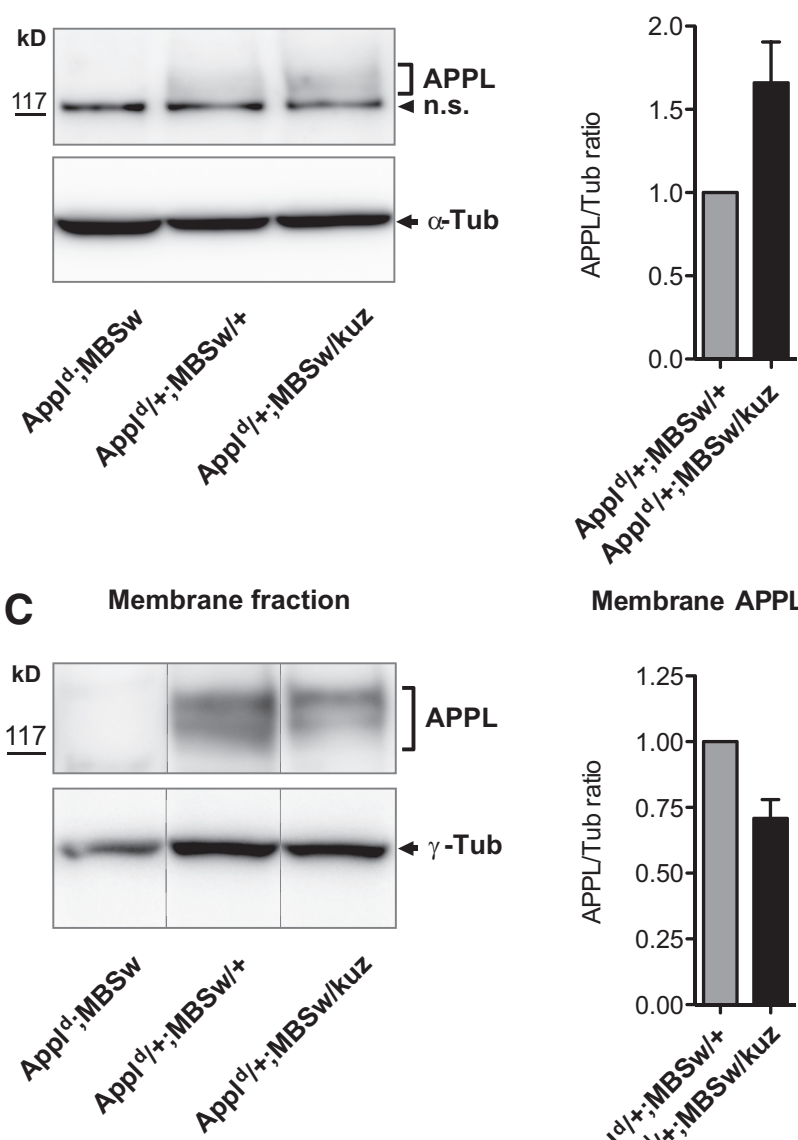

Membrane APPL

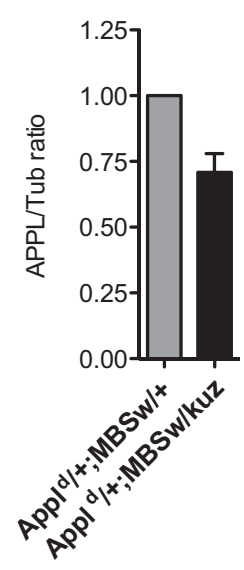

Figure 5. Impact of KUZ overexpression on App/ transcription and APPL processing. Flies were fed with RU for $48 \mathrm{~h}$ before RNA or protein extraction. $A, \mathrm{qPCR}$ analyses. Total RNA was extracted from $A p p I^{d} /+; M B S W /+$ and $A p p I^{d} /+; M B S w / k u z$ fly heads, and level is similar in $A p p I^{d} /+; M B S w /+$ and $A p p l^{d} /+; M B S w / k u z$ flies ( $t$ test, $\left.p=0.5814, n=3\right) . B, C$, Western blot analyses. Protein extracted from fly head lysates was fractionated $(n=3)$, and resulting blots were stained using an N-ter APPL-specific antibody. $\gamma$-Tub, respectively, relative to the $A p p I^{d} /+; M B S W /+$ control. $B$, Analyses of soluble fractions. Secreted-APPL level is increased in $A p p l /+; M B S w / k u z$ flies compared with $A p p I^{d} /+; M B S w /+$, while it is not detected in $A p p I^{d} ; M B S W$-null flies. n.s., Nonspecific gel, but not side to side. fl-APPL level is decreased in $\mathrm{Appl}^{d} /+; M B S W / k u z$ flies compared with $A p p l d /+; M B S W /+$ control flies Error bars indicate mean \pm SEM.

onstrate that expression of a nonprocessed APPL mutant form is able to restore wild-type memory in an APPL partial loss of function background.

In the past, two main strategies have been considered as therapeutic approaches for $\mathrm{AD}$. First, inhibition of the $\beta$ - or $\gamma$-secretase has been used to achieve an inhibition of $\mathrm{A} \beta$ toxic production (Wolfe, 2008). However, reduction of $A \beta$ production is not only an ineffective approach for AD (Callaway, 2012; Xia et al., 2012), it also can actually promote further pathology, as these enzymes have numerous substrates (Randall et al., 2010). A second proposed approach has been to inhibit the amyloidogenic pathway by activating the $\alpha$-processing of APP (Fahrenholz, 2007). In addition to the potential beneficial inhibition of the amyloidogenic pathway, the advantage of this type of approach is to also increase the production of sAPP $\alpha$ (Vincent and Govitrapong, 2011). Indeed, decreased CSF sAPP $\alpha$ levels were found in familial and sporadic AD patients (Lannfelt et al., 1995; Sennvik 
A
STM

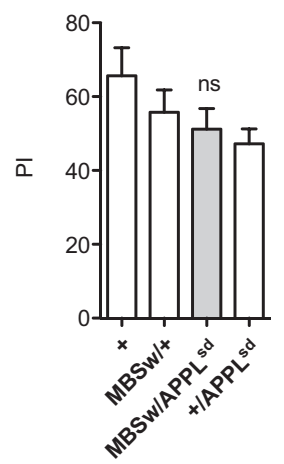

B

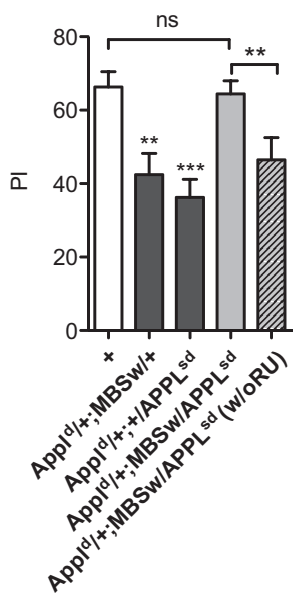

Figure 6. Transient expression of membrane-anchored $A P P L{ }^{\text {sd }}$ rescues the memory deficit caused by APPL partial LOF. Unless indicated ( $\boldsymbol{B}, \mathrm{w} / 0 \mathrm{RU})$, flies were fed with RU for $48 \mathrm{~h}$ before conditioning. Flies were submitted to one-cycle training and tested $2 \mathrm{~h}$ later. $\boldsymbol{A}, M B S W / A P P L^{5 d}$ flies exhibit STM performances similar to control groups $\left(F_{(3,39)}=1.693, p=0.1858, n \geq 7\right)$. $B, A p p I^{d} /+; M B S W / A P P L^{s d}$ flies display a memory score significantly higher than that of $\mathrm{Appl}^{d} /+$; $M B S W /+$ and $A p p I^{d} /+;+/ A P P L^{s d}$ flies $\left(F_{(4,85)}=8.023, p<0.0001, n \geq 13\right.$; Newman-Keuls posthoc, $A p p I^{d} /+M B S w / A P P L^{s d}$ vs Appl $/+; M B S W /+^{* *} p<0.005, A^{d}{ }^{*} I^{d} /+M B S w / A P P L^{s d}$ vs $\left.A p p I^{d} /+;+/ A P P L^{s d * * *} p<0.001\right)$, and similar to wild-type $(+)$ flies (Newman-Keuls post hoc, $p>0.05) . A p p I^{d} /+; M B S W / A P P L^{s d}$ flies not fed with RU exhibit scores indistinguishable from that of $A p p I^{d} /+; M B S W /+$ and $A p p I^{d} /+;+/ A P P L^{s d}$ flies (Newman-Keuls post hoc, $p>$ $0.05)$, and significantly lower than wild-type $(+)$ (Newman-Keuls post hoc, $\left.{ }^{*} p<0.05\right)$. Appl ${ }^{d} /+$; $M B S W / A P P L$ sd flies not fed with RU exhibit an STM score significantly decreased compared with the flies of the same genotype fed with RU (Newman-Keuls post hoc, ${ }^{* *} p<0.005$ ). Error bars indicate mean \pm SEM. PI, Performance Index.
A

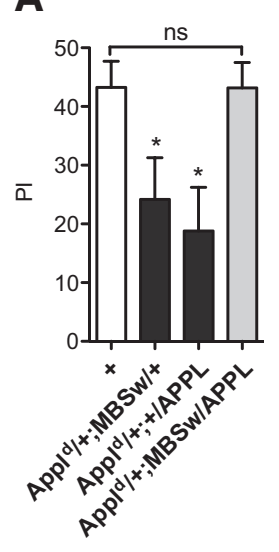

B

LTM

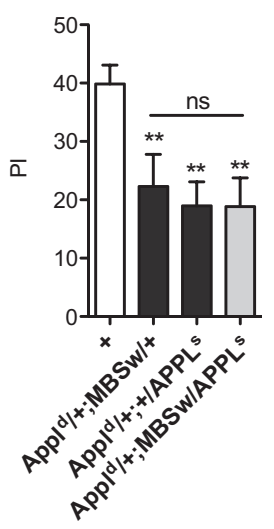

C

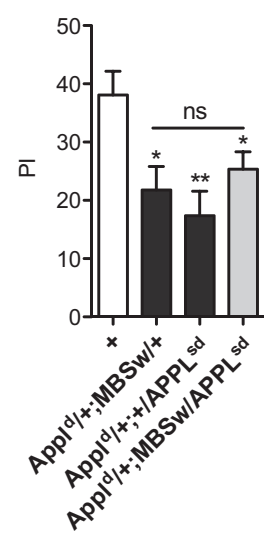

Figure 7. Analyses of LTM rescue. Flies were fed with RU for $48 \mathrm{~h}$ before five-spaced cycle conditioning, and also for $24 \mathrm{~h}$ until memory tests. $\boldsymbol{A}$, Expression of wild-type APPL restores wild-type LTM in $A p p I^{d} /+$ heterozygous flies. Appl $/+; M B S W / A P P L$ flies exhibit a score significantly higher than that of $A p p I^{d} /+; M B S W /+$ and $A p p I^{d} /+;+/ A P P L$ flies $\left(F_{(3,51)}=4.768, p\right.$ $0.0055, n \geq 11$; Newman-Keuls post hoc, $\left.{ }^{*} p<0.05\right)$, and indistinguishable from wild-type $(+)$ flies (Newman-Keuls post hoc, $p>0.05$ ). $\boldsymbol{B}$, APPL $^{5}$ overexpression does not rescue the LTM deficit caused by APPL partial LOF $\left(F_{(3,85)}=5.672, p=0.0014, n \geq 18\right)$. Appl $/+; M B S W /$ $A P P L^{s}$ flies display a memory deficit similar to that of $A p p I^{d} /+; M B S W /+$ and $A p p l /+;+/$ $A P P L^{s}$ flies, respectively (Newman-Keuls post hoc, $p>0.05$ ), and significantly lower than wild-type $(+)$ flies (Newman-Keuls posthoc, $\left.{ }^{* *} p<0.005\right)$. C, APPL ${ }^{\text {sd }}$ overexpression does not rescue the LTM deficit caused by APPL partial LOF $\left(F_{(3,95)}=5.460, p=0.0017, n \geq 22\right)$. $A p p I^{d} /+; M B S W / A P P L^{s d}$ flies display a memory deficit similar to that of $A p p I^{d} /+; M B S W /+$ and $A p p I^{d} /+;+/ A P P L^{s d}$ flies (Newman-Keuls post hoc, $p>0.05$ ), and significantly different from that of wild-type $(+)$ flies (Newman-Keuls post hoc, ${ }^{*} p<0.05$ ). Error bars indicate mean \pm SEM. PI, Performance Index. et al., 2000), and correlated with poor memory performance in patients with AD (Almkvist et al., 1997; Fellgiebel et al., 2009). Thus, in vitro and in vivo studies indicate that $\operatorname{sAPP} \alpha$ is downregulated during $\mathrm{AD}$. Numerous analyses have shown that sAPP $\alpha$ ectodomain has neurotrophic and neuroprotective effects in different models of neuronal stress (Mattson et al., 1993; Smith-Swintosky et al., 1994; Copanaki et al., 2010; Corrigan et al., 2011). In addition, sAPP $\alpha$ exhibits memory-enhancing properties. Intracerebroventricular infusion of anti-sAPP $\alpha$ serum was deleterious for memory, while that of sAPP $\alpha$ was beneficial (Meziane et al., 1998; Bour et al., 2004; Taylor et al., 2008). However, these studies relied on an exogenous excess of sAPP $\alpha$ and mechanisms of action and potential targets remained to be elucidated. With knock-in mice experiments, Ring et al. (2007) showed that sAPP $\alpha$ was sufficient to correct the impairments in spatial learning and long-term potentiation that are present in APP KO mice. Here we show in Drosophila that sAPPL is able to fully rescue the STM deficit caused by a reduction in endogenous APPL level, thus establishing that an APPL soluble form plays a role in memory, and giving further support for a role of secreted forms in memory in mammal systems.

When the fly $\alpha$-secretase, KUZ, was overexpressed in the adult $\mathrm{MB}$, we did not observe any STM-enhancing effect and, unexpectedly, KUZ overexpression in the MB of flies with an APPL partial loss of function exacerbated their memory impairment. Thus, KUZ overexpression was actually deleterious for memory, rather than beneficial. These results contrast with a previous study showing that overexpression of the mammalian $\alpha$-secretase ADAM10 in an AD mice model led to an increase in $\operatorname{sAPP} \alpha$, and was able to overcome APP-related learning deficits (Postina et al., 2004). However, these studies showed that $\alpha$-secretase activation has a positive impact on memory exclusively under conditions where human APP is overexpressed. In wild-type mice, results were not clear because overexpression of either the wild-type or an inactive form of the bovine ADAM10 altered learning and memory (Schmitt et al., 2006). Furthermore, ADAM10 has many substrates (Vincent and Checler, 2012), and no evidence was brought to link the memory deficit to APP.

Interestingly, we observed that KUZ overexpression decreases membrane nonproteolyzed APPL level, suggesting that its negative impact on memory in APPL LOF flies is linked to a reduction of nonproteolyzed APPL level. Therefore, strategies aimed at increasing APP $\alpha$-cleavage may not be appropriate as this could provoke a decrease of fl-APP levels that might be deleterious to APP function.

Transient expression of a constitutive membrane-bound mutant APPL has the capacity to fully rescue the STM deficit caused by APPL partial loss of function. Thus, both sAPPL and fl-APPL appear to be involved in memory processes. This is in apparent contradiction with the observation that mammalian $\operatorname{sAPP} \alpha$ was sufficient to correct spatial learning deficit of APP KO mice (Ring et al., 2007). However, in this study APP-like proteins APLP1 and ALPL2 were preserved, and as it is known from double $\mathrm{KO}$ analyses that the three APP homologs exert functional redundancy (Anliker and Müller, 2006), they may have compensated for the loss of essential fl-APP functions. In consequence, one cannot attribute the memory function exclusively to sAPP $\alpha$.

If both fl-APPL and sAPPL carry the capacity to restore wildtype STM in APPL partial LOF flies, it is puzzling to observe that KUZ overexpression in this genetic context is deleterious for memory. Indeed, in addition to causing a decrease in fl-APPL, KUZ overexpression leads to a concomitant increase in SAPPL 
that should be able to complement fl-APPL deficiency. We suggest that in this context, fl-APPL level is below threshold so that even high levels of sAPPL cannot restore a wild-type memory. This hypothesis is supported by protein quantification experiments showing a $30 \%$ decrease in fl-APPL level. Because APPL was extracted from the whole brain, whereas KUZ overexpression was only driven in a subset of neurons, the effective fl-APPL decrease in the MB must be much higher than $30 \%$.

In mammalian cells under steady-state levels, $\sim 10 \%$ of APP is located at the plasma membrane (Thinakaran and Koo, 2008). APP has long been suggested to act as a cell-surface receptor (Kang et al., 1987); however, such a function has not been unequivocally established. Several reports have shown that APP exists as homodimers (Scheuermann et al., 2001; Soba et al., 2005; Dahms et al., 2010). Cis-dimerization of APP would represent a potential mechanism for a negative regulation of APP functions and a concomitant impact on $\mathrm{A} \beta$ generation via an increase in $\beta$-processing (Scheuermann et al., 2001; Hashimoto et al., 2003; Lu et al., 2003; Kedikian et al., 2010; Lefort et al., 2012). Interestingly, it has been suggested that APP is a receptor for $\operatorname{APP} \alpha$ as its binding could disrupt APP dimers (Gralle et al., 2009).

In Drosophila, Wentzell et al. (2012) reported that the secreted $\mathrm{N}$-terminal ectodomain of APPL acts as a soluble ligand for neuroprotective functions. Furthermore, coimmunoprecipitation experiments from transfected Drosophila MB intrinsic cells revealed a physical interaction between fl-APPL and SAPPL, suggesting that sAPPL could be a ligand for fl-APPL (Wentzell et al., 2012). Our data showing the involvement of both membrane fl-APPL and sAPPL in memory are consistent with the hypothesis that sAPPL could be a ligand for its own fl-APPL precursor.

In conclusion, our data reveal for the first time a role for membrane fl-APPL in memory, opening new questions about APP nonpathological functions and relations between secreted and full-length forms in memory processes.

\section{References}

Almkvist O, Basun H, Wagner SL, Rowe BA, Wahlund LO, Lannfelt L (1997) Cerebrospinal fluid levels of alpha-secretase-cleaved soluble amyloid precursor protein mirror cognition in a Swedish family with Alzheimer disease and a gene mutation. Arch Neurol 54:641-644. CrossRef Medline

Anliker B, Müller U (2006) The functions of mammalian amyloid precursor protein and related amyloid precursor-like proteins. Neurodegener Dis 3:239-246. CrossRef Medline

Bour A, Little S, Dodart JC, Kelche C, Mathis C (2004) A secreted form of the beta-amyloid precursor protein (sAPP695) improves spatial recognition memory in OF1 mice. Neurobiol Learn Mem 81:27-38. CrossRef Medline

Callaway E (2012) Alzheimer's drugs take a new tack. Nature 489:13-14. CrossRef Medline

Carmine-Simmen K, Proctor T, Tschäpe J, Poeck B, Triphan T, Strauss R, Kretzschmar D (2009) Neurotoxic effects induced by the Drosophila amyloid- $\beta$ peptide suggest a conserved toxic function. Neurobiol Dis 33:274-281. CrossRef Medline

Copanaki E, Chang S, Vlachos A, Tschäpe JA, Müller UC, Kögel D, Deller T (2010) sAPP $\alpha$ antagonizes dendritic degeneration and neuron death triggered by proteasomal stress. Mol Cell Neurosci 44:386-393. CrossRef Medline

Corrigan F, Pham CL, Vink R, Blumbergs PC, Masters CL, van den Heuvel C, Cappai R (2011) The neuroprotective domains of the amyloid precursor protein, in traumatic brain injury, are located in the two growth factor domains. Brain Res 1378:137-143. CrossRef Medline

Dahms SO, Hoefgen S, Roeser D, Schlott B, Gührs KH, Than ME (2010) Structure and biochemical analysis of the heparin-induced E1 dimer of the amyloid precursor protein. Proc Natl Acad Sci U S A 107:5381-5386. CrossRef Medline

Dubnau J, Tully T (1998) Gene discovery in Drosophila: new insights for learning and memory. Annu Rev Neurosci 21:407-444. CrossRef Medline
Fahrenholz F (2007) Alpha-secretase as a therapeutic target. Curr Alzheimer Res 4:412-417. CrossRef Medline

Fellgiebel A, Kojro E, Müller MJ, Scheurich A, Schmidt LG, Fahrenholz F (2009) CSF APPs alpha and phosphorylated tau protein levels in mild cognitive impairment and dementia of Alzheimer's type. J Geriatr Psychiatry Neurol 22:3-9. CrossRef Medline

Förstl H, Kurz A (1999) Clinical features of Alzheimer's disease. Eur Arch Psychiatry Clin Neurosci 249:288-290. CrossRef Medline

Goguel V, Belair AL, Ayaz D, Lampin-Saint-Amaux A, Scaplehorn N, Hassan BA, Preat T (2011) Drosophila amyloid precursor protein-like is required for long-term memory. J Neurosci 31:1032-1037. CrossRef Medline

Gralle M, Botelho MG, Wouters FS (2009) Neuroprotective secreted amyloid precursor protein acts by disrupting amyloid precursor protein dimers. J Biol Chem 284:15016-15025. CrossRef Medline

Hardy J, Selkoe DJ (2002) The amyloid hypothesis of Alzheimer's disease: progress and problems on the road to therapeutics. Science 297:353-356. CrossRef Medline

Hashimoto Y, Tsuji O, Niikura T, Yamagishi Y, Ishizaka M, Kawasumi M, Chiba T, Kanekura K, Yamada M, Tsukamoto E, Kouyama K, Terashita K, Aiso S, Lin A, Nishimoto I (2003) Involvement of c-Jun N-terminal kinase in amyloid precursor protein-mediated neuronal cell death. J Neurochem 84:864-877. CrossRef Medline

Heber S, Herms J, Gajic V, Hainfellner J, Aguzzi A, Rülicke T, von Kretzschmar H, von Koch C, Sisodia S, Tremml P, Lipp HP, Wolfer DP, Müller U (2000) Mice with combined gene knock-outs reveal essential and partially redundant functions of amyloid precursor protein family members. J Neurosci 20:7951-7963. Medline

Heisenberg M (1998) What do the mushroom bodies do for the insect brain? An introduction. Learn Mem 5:1-10. Medline

Herms J, Anliker B, Heber S, Ring S, Fuhrmann M, Kretzschmar H, Sisodia S, Müller U (2004) Cortical dysplasia resembling human type 2 lissencephaly in mice lacking all three APP family members. EMBO J 23:41064115. CrossRef Medline

Kang J, Lemaire HG, Unterbeck A, Salbaum JM, Masters CL, Grzeschik KH, Multhaup G, Beyreuther K, Müller-Hill B (1987) The precursor of Alzheimer's disease amyloid A4 protein resembles a cell-surface receptor. Nature 325:733-736. CrossRef Medline

Kedikian G, Heredia F, Salvador VR, Raimunda D, Isoardi N, Heredia L, Lorenzo A (2010) Secreted amyloid precursor protein and holo-APP bind amyloid beta through distinct domains eliciting different toxic responses on hippocampal neurons. J Neurosci Res 88:1795-1803. Medline

Lallemand D, Curto M, Saotome I, Giovannini M, McClatchey AI (2003) NF2 deficiency promotes tumorigenesis and metastasis by destabilizing adherens junctions. Genes Dev 17:1090-1100. CrossRef Medline

Lannfelt L, Basun H, Vigo-Pelfrey C, Wahlund LO, Winblad B, Lieberburg I, Schenk D (1995) Amyloid beta-peptide in cerebrospinal fluid in individuals with the Swedish Alzheimer amyloid precursor protein mutation. Neurosci Lett 199:203-206. CrossRef Medline

Lefort R, Pozueta J, Shelanski M (2012) Cross-linking of cell surface amyloid precursor protein leads to increased $\beta$-amyloid peptide production in hippocampal neurons: implications for Alzheimer's disease. J Neurosci 32:10674-10685. CrossRef Medline

Li Y, Liu T, Peng Y, Yuan C, Guo A (2004) Specific functions of Drosophila amyloid precursor-like protein in the development of nervous system and nonneural tissues. J Neurobiol 61:343-358. CrossRef Medline

Lieber T, Kidd S, Young MW (2002) Kuzbanian-mediated cleavage of Drosophila Notch. Genes Dev 16:209-221. CrossRef Medline

Lu DC, Soriano S, Bredesen DE, Koo EH (2003) Caspase cleavage of the amyloid precursor protein modulates amyloid beta-protein toxicity. J Neurochem 87:733-741. CrossRef Medline

Luo L, Tully T, White K (1992) Human amyloid precursor protein ameliorates behavioral deficit of flies deleted for Appl gene. Neuron 9:595-605. CrossRef Medline

Mao Z, Roman G, Zong L, Davis RL (2004) Pharmacogenetic rescue in time and space of the rutabaga memory impairment by using Gene-Switch. Proc Natl Acad Sci U S A 101:198-203. CrossRef Medline

Mattson MP, Cheng B, Culwell AR, Esch FS, Lieberburg I, Rydel RE (1993) Evidence for excitoprotective and intraneuronal calcium-regulating roles for secreted forms of the beta-amyloid precursor protein. Neuron 10:243254. CrossRef Medline

McGuire SE, Deshazer M, Davis RL (2005) Thirty years of olfactory learning 
and memory research in Drosophila melanogaster. Prog Neurobiol 76: 328-347. CrossRef Medline

Meziane H, Dodart JC, Mathis C, Little S, Clemens J, Paul SM, Ungerer A (1998) Memory-enhancing effects of secreted forms of the beta-amyloid precursor protein in normal and amnestic mice. Proc Natl Acad Sci U S A 95:12683-12688. CrossRef Medline

Neve RL, McPhie DL, Chen Y (2000) Alzheimer's disease: a dysfunction of the amyloid precursor protein. Brain Res 886:54-66. CrossRef Medline

Pan D, Rubin GM (1997) Kuzbanian controls proteolytic processing of Notch and mediates lateral inhibition during Drosophila and vertebrate neurogenesis. Cell 90:271-280. CrossRef Medline

Pascual A, Préat T (2001) Localization of long-term memory within the Drosophila mushroom body. Science 294:1115-1117. CrossRef Medline

Poeck B, Strauss R, Kretzschmar D (2012) Analysis of amyloid precursor protein function in Drosophila melanogaster. Exp Brain Res 217:413-421. CrossRef Medline

Postina R, Schroeder A, Dewachter I, Bohl J, Schmitt U, Kojro E, Prinzen C, Endres K, Hiemke C, Blessing M, Flamez P, Dequenne A, Godaux E, van Leuven F, Fahrenholz F (2004) A disintegrin-metalloproteinase prevents amyloid plaque formation and hippocampal defects in an Alzheimer disease mouse model. J Clin Invest 113:1456-1464. CrossRef Medline

Randall AD, Witton J, Booth C, Hynes-Allen A, Brown JT (2010) The functional neurophysiology of the amyloid precursor protein (APP) processing pathway. Neuropharmacology 59:243-267. CrossRef Medline

Ring S, Weyer SW, Kilian SB, Waldron E, Pietrzik CU, Filippov MA, Herms J, Buchholz C, Eckman CB, Korte M, Wolfer DP, Müller UC (2007) The secreted-amyloid precursor protein ectodomain APPs is sufficient to rescue the anatomical, behavioral, and electrophysiological abnormalities of APP-deficient mice. J Neurosci 27:7817-7826. CrossRef Medline

Roman G, Endo K, Zong L, Davis RL (2001) P[Switch], a system for spatial and temporal control of gene expression in Drosophila melanogaster. Proc Natl Acad Sci U S A 98:12602-12607. CrossRef Medline

Rooke J, Pan D, Xu T, Rubin GM (1996) KUZ, a conserved metalloproteasedisintegrin protein with two roles in Drosophila neurogenesis. Science 273:1227-1231. CrossRef Medline

Scheuermann S, Hambsch B, Hesse L, Stumm J, Schmidt C, Beher D, Bayer TA, Beyreuther K, Multhaup G (2001) Homodimerization of amyloid precursor protein and its implication in the amyloidogenic pathway of Alzheimer's disease. J Biol Chem 276:33923-33929. CrossRef Medline

Schmitt U, Hiemke C, Fahrenholz F, Schroeder A (2006) Over-expression of two different forms of the alpha-secretase ADAM10 affects learning and memory in mice. Behav Brain Res 175:278-284. CrossRef Medline

Sennvik K, Fastbom J, Blomberg M, Wahlund LO, Winblad B, Benedikz E (2000) Levels of alpha- and beta-secretase cleaved amyloid precursor protein in the cerebrospinal fluid of Alzheimer's disease patients. Neurosci Lett 278:169-172. CrossRef Medline

Smith-Swintosky VL, Pettigrew LC, Craddock SD, Culwell AR, Rydel RE, Mattson MP (1994) Secreted forms of beta-amyloid precursor protein protect against ischemic brain injury. J Neurochem 63:781-784. CrossRef Medline

Soba P, Eggert S, Wagner K, Zentgraf H, Siehl K, Kreger S, Löwer A, Langer A, Merdes G, Paro R, Masters CL, Müller U, Kins S, Beyreuther K (2005) Homo- and heterodimerization of APP family members promotes intercellular adhesion. EMBO J 24:3624-3634. CrossRef Medline

Soldano A, Okray Z, Janovska P, Tmejová K, Reynaud E, Claeys A, Yan J, Atak ZK, De Strooper B, Dura JM, Bryja V, Hassan BA (2013) The Drosophila Homologue of the Amyloid Precursor Protein Is a Conserved Modulator of Wnt PCP Signaling. PLoS Biol 11:e1001562. CrossRef Medline

Taylor CJ, Ireland DR, Ballagh I, Bourne K, Marechal NM, Turner PR, Bilkey DK, Tate WP, Abraham WC (2008) Endogenous secreted amyloid precursor protein-alpha regulates hippocampal NMDA receptor function, long-term potentiation and spatial memory. Neurobiol Dis 31:250-260. CrossRef Medline

Thinakaran G, Koo EH (2008) Amyloid precursor protein trafficking, processing, and function. J Biol Chem 283:29615-29619. CrossRef Medline

Torroja L, Luo L, White K (1996) APPL, the Drosophila member of the APP-family, exhibits differential trafficking and processing in CNS neurons. J Neurosci 16:4638-4650. Medline

Torroja L, Packard M, Gorczyca M, White K, Budnik V (1999) The Drosophila beta-amyloid precursor protein homolog promotes synapse differentiation at the neuromuscular junction. J Neurosci 19:7793-7803. Medline

Tully T, Quinn WG (1985) Classical conditioning and retention in normal and mutant Drosophila melanogaster. J Comp Physiol A 157:263-277. CrossRef Medline

Tully T, Preat T, Boynton SC, Del Vecchio M (1994) Genetic dissection of consolidated memory in Drosophila. Cell 79:35-47. CrossRef Medline

Turner PR, O'Connor K, Tate WP, Abraham WC (2003) Roles of amyloid precursor protein and its fragments in regulating neural activity, plasticity and memory. Prog Neurobiol 70:1-32. CrossRef Medline

Vincent B, Checler F (2012) $\alpha$-Secretase in Alzheimer's disease and beyond: mechanistic, regulation and function in the shedding of membrane proteins. Curr Alzheimer Res 9:140-156. CrossRef Medline

Vincent B, Govitrapong P (2011) Activation of the $\alpha$-secretase processing of $\mathrm{A} \beta \mathrm{PP}$ as a therapeutic approach in Alzheimer's disease. J Alzheimers Dis 24 [Suppl 2]:75-94. CrossRef Medline

Wentzell JS, Bolkan BJ, Carmine-Simmen K, Swanson TL, Musashe DT, Kretzschmar D (2012) Amyloid precursor proteins are protective in Drosophila models of progressive neurodegeneration. Neurobiol Dis 46: 78-87. CrossRef Medline

Wolfe MS (2008) Selective amyloid- $\beta$ lowering agents. BMC Neurosci 9:S4. CrossRef Medline

Xia W, Wong ST, Hanlon E, Morin P (2012) $\gamma$-Secretase modulator in Alzheimer's disease: shifting the end. J Alzheimers Dis 31:685-696. CrossRef Medline

Zheng H, Koo EH (2011) Biology and pathophysiology of the amyloid precursor protein. Mol Neurodegener 6:27. CrossRef Medline 